\title{
大ロ径パイプを用いた簡易不攪乱柱状採泥器の試作
}

井 澤 博 文* 清 木 徹* 伊 達 悦 二*

\section{The Design of the Simple Core Sampler}

\section{Hirofumi IZAWA*, Tohru SEIKI* and Etsuji DATE*}

Hiroshima prefectural research center for environmental science, 1-6-29, Minami-machi, Minami-ku, Hiroshima -shi, Hiroshima 734 Japan

\section{1.はじめに}

底質の分布は水平方向だけでなく垂直方向にも大き く変化して抢り，その性状を的確に評価，比較するた めにはグラブ型採泥器のように一塊の泥として採取す る方法は好ましくない。特に, 底泥からの溶出量や堆 積状況をみる場合には，不攪乱柱状泥を得ることが前 提となる。

従来，柱状採泥をするにあたっては小口径（約 40 $\mathrm{mm})$ の採泥器が多く使われて扔り ${ }^{1)}$, この場合採泥コ アの短縮や表層泥の乱れ，また，分析や実験にあたっ て容量不足になる場合も多かった。採泥コアの短縮を 防ぐためにはピストン式による採泥2)，または口径を 大きくする方法がある。ピストン式による方法は表層 部の乱れを幾分伴らことから，極表層部の泥や，直上 水を採取する目的には適さない。大口径パイプによる 方法は表層部の乱れやコアの短縮を起こさない点や， 採泥量が多い点などメリットも大きいが，採取した泥 の脱落防止法や装置の大型化, 重量化が問題となり, 従来実用的なものはなかった ${ }^{3)}$ 。

今回の装置はこのような点を考慮し，大口径化と同 時に操作の簡易化を视らい，乙か子確実に不攪乱柱状 泥が採取できることを目的として試作した。

\section{2 . 装置の概要}

装置の概略をFig.1 1 亿示す。本装置は, 採泥器本体,
採泥用パイプそして扣もりの部分から成る。

装置本体はステンレス製で重量約 $2 \mathrm{~kg}$, 長さ約 1.5 $\mathrm{m}$, 本体下端部には底泥脱落防止用の円形コア保持バ ルブ(6)をつけているのが特徵で，上部の吊り下げパイ プ(1)とつながっている。吊り下げパイプ(1)の上端には 自在フック(7)を取り付けるためのリングがあり, 途中, 引き上げ用のワイヤ(8)が内部を通って自在フック (7)と トリガー軸(2)につながっている。トリガー軸(2)の両端 は吊り下げパイプ(1)に留められて打り，その内側に， パイプ固定枠(5)の上端が連結できるようになってい る。吊り下げパイプ(1)の下部は 2 方に分かれ，一方の 下端部にコア保持バルプ(6)が連結されており，他方の 下端部と共に，引き上げ時のパイプ固定枠(5)の支持点 ともなる。コア保持バルプ(6)図のように, 円筒の一 部を切り取った形をしている。このバルプはパイプ固 定枠(5)の端部を軸に回転できるようになって招り， 開放時には，パイプ固定枠(5)の内側に沿った状態で円 筒状に通じた形になる。また，閉塞時は $90^{\circ}$ 回転し，パ イプ固定枠(5)の下端部を完全に閉じる機能を持ってい る。パイプ固定枠(5は採泥用アクリルパイプを装着す る部分であり，下部には採泥用パイプをはめ込むため の枠を備觉，その内側にパイプを支党るための小突起 を備光ている。さらに，この枠の一部に底板差し込み 口(4)として開口部を設け，採泥後，底泥試料の入った パイプを取り出すための柄のついた円盤状底板を差し 込めるようにしている。また，上部には吊り下げパイ

* 広島県環境センター $\bar{T} 734$ 広島市南区皆実町 1-6-29 


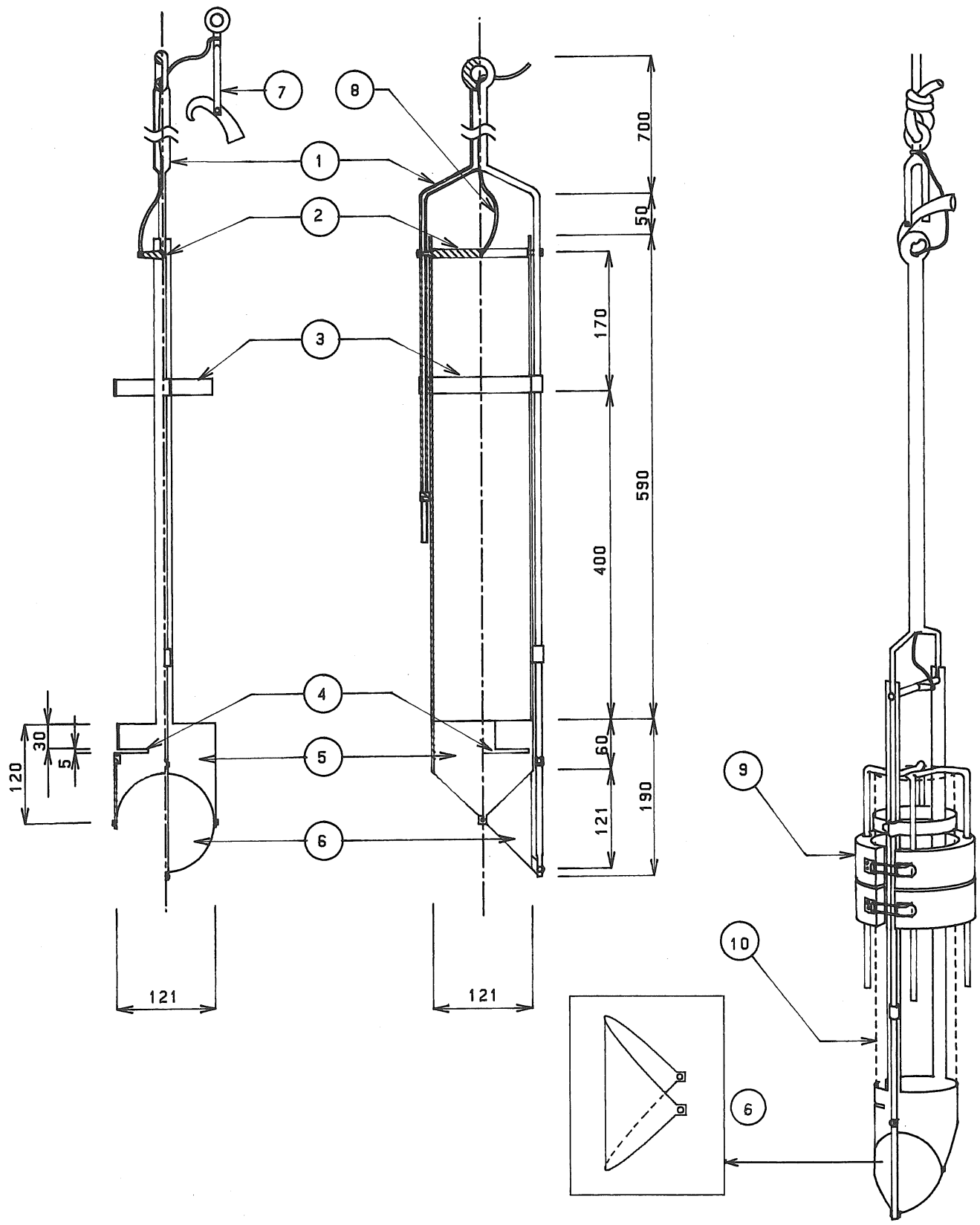

Fig. 1 Drawing of new type core sampler for undisturbed sediment (1)Frame pipe (2)Trigger rod, supporting axle (3)Supporting guide for acrylic tube (4)Opening for insertion of pipe-end closer (5)Supporitng frame for acrylic tube (6) Core-retainer, to hold sampled core (7)Hook (8)Wire (9)Weight, lead (10)Acrylic core tube

プに沿って枠の一部が延びて扣り，途中には採泥用ア クリルパイプを保持するためのパイプガイド(3)がつい ている。このパイプ固定枠(5)の上部先端はトリガー軸 (2)の両端に直接，接続できるようになっている。
採泥用パイプは内径 $110 \mathrm{~mm}$, 長さ $500 \mathrm{~mm}$ のアクリ ル製円筒10を用いる。このパイプの下部には採泥後の 底泥試料を保持または運搬するための底フタ装着用の 懸け金用突起部を付けている。 


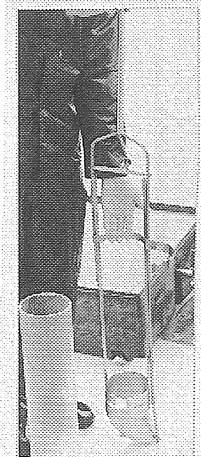

2

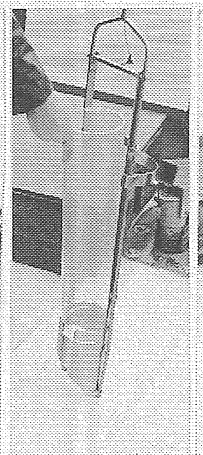

b

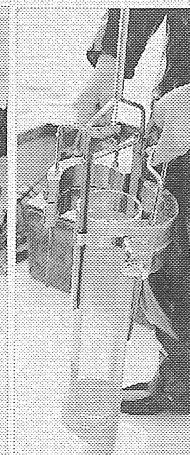

c

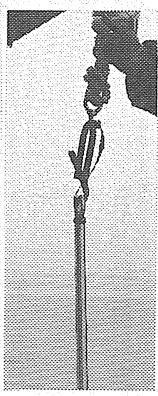

d
Fig. 2 Preparation for sampling

a) Setting of core-retainer with trigger rod

b) Setting of acrylic core tube into supporting frame

c) Hunging of weight onto top of acrylic core tube

d) Hanging by hook

扣もり (9)は重量約 $5 \mathrm{~kg}$ の括もりを適当数（2 個前 後）セットする。この拈もりは蝶番により左右に開く ことができ，採泥時にアクリルパイプ(10)をはさんでそ の上縁に懸けることにより装着する。

\section{3. 採泥方法及びその機構}

\section{1 採泥準備}

予め, トリガー軸にパイプ固定枠を接続することに よりコア保持バルブを開いた状態にセットし（Fig.2 -a), アクリルパイプを装着する (Fig. 2-b)。次いで, おもりを装着（Fig.2-c)し，引き上げ用ロープをつな いだ自在フックをかける（Fig.2-d）。

\section{2 採泥機構}

採泥機構を Fig.3, 4 に示す。自在フックでつながれ た状態の本装置を船上から静かに下ろし，自重により 底泥に貫入させる。この時, コア保持バルブは解放状 態にあり，トリガー軸と自在フックを結んでいるワイ ヤは緩んだ状態にある。貫入が止まった時点で，引き 上げロープの張力がなくなり, 自在フックがはずれる。 引き上げ時にはワイヤが上部に引っ張られるため, ト リガー軸が回転し，吊り下げ用パイプとパイプ固定枠 が分離される。これにより吊り下げパイプのみ上へス ライドし，同時にコア保持バルブが $90^{\circ}$ 回転してコア下 端部を切断, 閉塞し, 引き上げ時に扣ける底泥試料の 脱落を防ぐ。

\section{3 底泥試料の回収}

底泥試料の回収の様子を Fig. 5 に示す。引き上げ

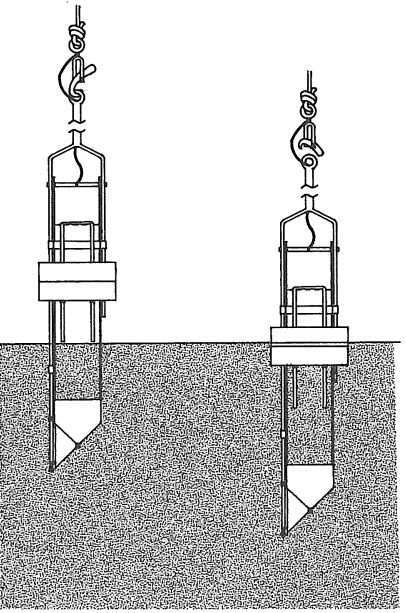

(1)
(2)

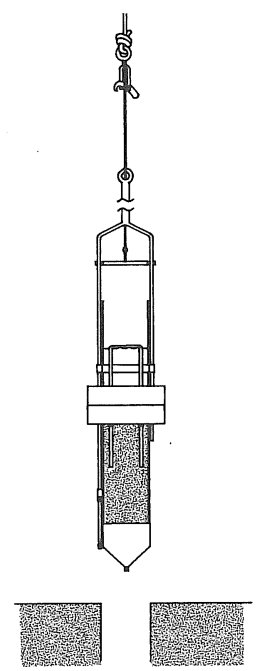

(3)
Fig. 3 Sampling scheme

(1) Penetration (2) Standing and removing of hook (3) Pull up and close of core-retainer

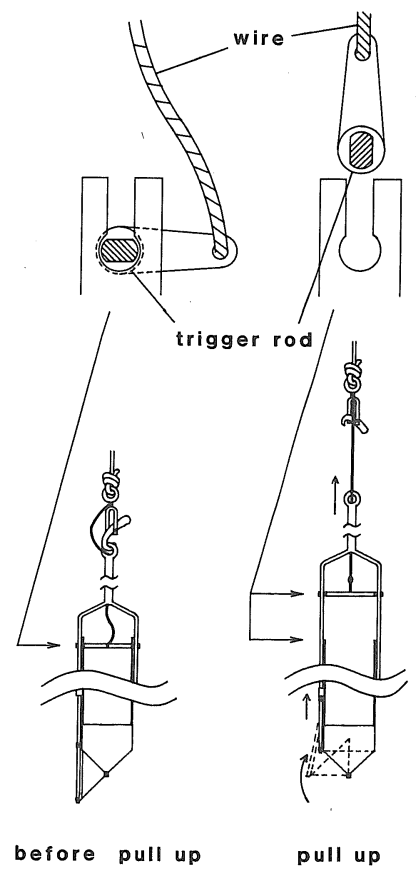

Fig. 4 Working mechanism of core-retainer and trigger

後, おもりを取り外し (a), 心持ちアクリルパイプを上 万へ持ち上げ，底板差し込み口に底板を插入する(b)。 試科パイプ下端からの底泥の漏出を防ぐよう底板を添 えたまま，予め用意した底フタの上に試料パイプをお 




Fig. 5 Recovery of sediment core

a) Just after sampling

b) Unfastening supporting guide of acrylic tube and inserting of supporting plate for taking out

c) Taking out of core tube

d) Putting on a prepared bottom lid

e) Combining the lid with core tube by wire

f) Setting inner cap for carrying to laboratory

き(c)，底板を引き抜く(d)。底板がはずれないよら試 料パイプと底板を針金で結束する(e)。な拈，移送する にあたって，著者らは底泥直上水の乱れを防ぐため中 フタを用いて直上水を密封し $(\mathbf{f})$ ，運搬している。

\section{4. 採泥試 験}

本装置で不攪乱状態の採泥ができるかどらかの試験 を行った。ここで言ら不攪乱とは，底泥表層和よび直 上水の乱れを伴わないこと，底泥への貫入長と採泥長 が等しいこと（コアの短縮が起きないこと）をいい， この点について試験を行った。底泥表層, 直上水の乱 れの有無は現場採泥実験時にダイバーによる水中での 目視执よび船上に引き上げて後の目視により，乱れな いことを確認した。また，装置先端部が斜めになって いることによる垂直貫入への影響がないこともダイ バーによる目視により確認した。

一方，コアの短縮は一般にパイプの径が小さくなる に従って，短縮率が大きくなる傾向にあると言われて いる3 。そこで軟泥質を用いた場合のパイプロ径と採

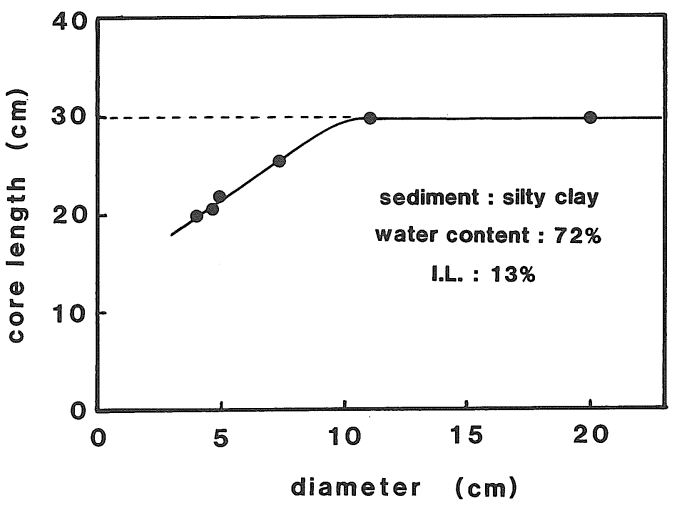

Fig. 6 Relation between diameter of acrylic core tube and length of sampled core

泥コア長の関係を調べるため不攪乱泥を用いた室内実 験を行った。Fig. 6 に種々の口径のアクリルパイプを 一定の深さ (約 $30 \mathrm{~cm}$ ) 挿入し, 得られたコアの長さを 比較した結果を示す。口径 $10 \mathrm{~cm}$ 以下ではュアの短縮 が起こるが, 本装置の口径では短縮が起こらなかった。 しかし， $30 \mathrm{~cm}$ 以上の貫入ではコアの短縮が起こり始 め, 現場での採泥実験で約 $50 \mathrm{~cm}$ 貫入した場合, 最大 5 $\mathrm{cm}$ 程度の短縮が起こることがあった。コアの短縮は 底質の性状によっても大きく変わるが, 通常, 湖沼, 海域に扣ける軟泥質の底質で, かつ $30 \mathrm{~cm}$ 以下の貫入 長であればほとんど無視できると思われる。

\section{5 . 試作採泥器の特徵}

本装置の特徴は底泥の脱落を防ぐためのコア保持バ ルブの工夫をした点と装置本体执よび採泥機構を簡略 化した点にある。これにより，採泥パイプの口径を大 きくすることができ，操作性の向上と採泥の確実性を 持たせることができた。本装置は $30 \mathrm{~cm}$ 以浅の不攪乱 柱状泥の採取に適しているが，砂質泥や河川底質のよ らな硬い底質の採取には適さない。

（原稿受理 1990年 1 月 30 日）

\section{引用 文 献}

1）社団法人日本水質污濁研究協会編（1982）「湖沼環境調査指 針」, 162，公害対策技術同友会，東京.

2 ) 井澤博文, 清木徹 (1985) 不攪乱柱状採泥器の試作, 広島県 環境センター研究報告, 7, 7-10.

3 ）日本鉱業会編 (1975)「海底サンプリングハンドブック」, 310 pp., ラティス, 東京. 


\section{GC/MS を用いた水中の有害化学物質のスクリーニング法}

森本 美鈴* 内村 豊* 原口 公子* 篠原 亮太**

* 北九州市環境衛生研究所 $* *$ 北九州市環境局環境保全部

〈水質污濁研究 Vol. 13 No. 5 （1990） pp.311 319〉

農薬等有害化学物質による魚類整死等の污染事故の原因物質の究明のため, GC/MS-SIM によるスクリーニ ング法の開発を試みた。対象物質には, 広く使用されている農薬の他に, 残留性が問題となっている有害化学 物質を計34種選んだ。

水質試料から有害化学物質をジクロロメタンまたはへキサンで抽出し, クリーンアップ処理をせず GC/MS -SIM で測定した。

検出限界は, 農薬類の魚類への急性毒性が $0.5 \sim 10 \mathrm{mg} \cdot l^{-1}$ であり, 污染事故発生から分析時までの分解と分析 精度を考慮して $0.01 \mathrm{mg} ・ l^{-1}$ とした。

回収率試験の結果，ジクロロメタンの回収率は，67１17\%で，へキサンの51９7\%より良好であった。

この方法で実際の河川水を分析したところ， $\mu \mathrm{g} \bullet l^{-1} レ$ ルのCAT, TPN，フルトラニン，イソプロチオラ ンが検出された。

\section{大ロ径パイプを用いた簡易不攪乱柱状採泥器の試作}

井澤 博文* 清木 徹* 伊達 悦二*

* 広島県環境センター

〈水質污濁研究 Vol. 13 No. 5 （1990） pp.320 323〉

底質調査に必要とされる不攪乱状態の底質を採取するためのコアサンプラーを試作した。この装置は本体(約 $2 \mathrm{~kg})$, 括もり $(5 \mathrm{~kg} \times 2)$, アクリルパイプ $(12 \mathrm{~cm} \times 50 \mathrm{~cm})$ の部分からなり, 全重量約 $13 \mathrm{~kg}$, 全長約 $1.5 \mathrm{~m}$ で人力による採泥が可能である。採泥はロープにつないだ本装置を静かに底泥中に貫入させた後引き上げるこ

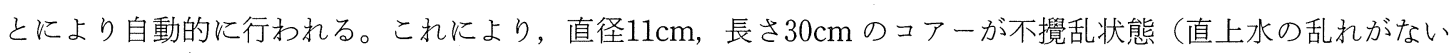
こと,コアーの短縮がないこと）で採取できる。本装置の特徵は採泥器先端のバルブの工夫と機構の簡素化に あり, これにより採泥コアー径の増大, 不攪乱柱状採泥, 操作性の簡易化そして採泥の確実性を持たせること ができた。

本装置は軟泥質の採泥に適して䄧り，砂質，れき質のような硬い底質は採取できない。 